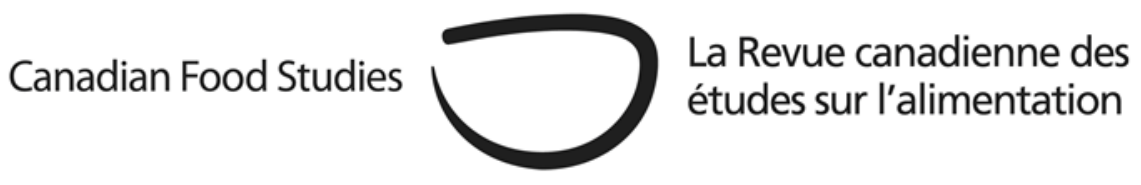

Field Report

\title{
Opportunities for and challenges of developing a culinary food studies Bachelor's degree
}

\author{
Caitlin Scott* and Lori Stahlbrand
}

George Brown College

\section{Abstract}

Although Food Studies has been acknowledged as a distinctive field in Canada for almost two decades, until now there has not been an undergraduate degree in Food Studies in this country. This is changing with the development of Canada's first Honours Bachelor's Degree in Food Studies (BFS) at George Brown College, launched in September 2021. This field report describes the process, opportunities, and challenges of developing a Food Studies degree at an Ontario college. It explores the unique openings at the intersection of food studies education and applied practical skills training for work in the food sector. In particular, we ask: What can food studies bring to culinary education? And, what can culinary education bring to food studies? We contend that food studies can contribute to a more transformative culinary education focussed on social, cultural, political, and environmental influences in the food system. Simultaneously, culinary education brings distinct insights into operationalization within the food sector which provide new openings for applied research in food studies. We demonstrate how this new collaboration and knowledge are a necessity in a turbulent world.

Keywords: Pedagogy; food studies; culinary arts 


\section{Introduction}

Food studies has been acknowledged as a distinct field in Canada for only two decades, yet it has emerged as a dynamic field, attracting some of the best and the brightest scholars and students. One of the reasons for this is the increasing understanding that food connects us all (The Metcalf Foundation, 2008). This rising interest has led to an explosion of books and specialized journals on all aspects of food, reflecting the fast pace of change in the food industry and in food habits. As well, there has been a steady emergence of new food studies and food systems programs, certificates, and specializations across North America (Hilimire \& McLaughlin, 2015; Jacobsen et al., 2012; Valley et al., 2018). However, culinary professionals have often been left out of food studies programs that focus on agronomy and nutrition. George Brown College has developed Canada's first Honours Bachelor of Food Studies, combining culinary training with a comprehensive food studies education.

This field report details the process, opportunities, and challenges of developing a Food Studies degree at an Ontario college and exposes the unique openings provided by the intersection between key principles of food studies education and applied practical skills training for work in the food sector. It attends to the questions: What can food studies bring to culinary education? And, what can culinary education bring to food studies? The combination provides new possibilities for enhancing the transformative potential of culinary education in Canada. Food studies has long been interested in activist-scholarship that sees academics co-developing research with local organizations. The vision for this degree is to offer a new point of entry, where food scholarship reaches the next generation of food industry workers to build unique skills and knowledge in interdisciplinary food studies research, non-profit work, and culinary arts - a combination that will prepare graduates to operationalize meaningful change within the sector. The need to operationalize change in the food system is no longer up for debate, but the best points of entry and methods are heavily contested. The goal of this program is to prepare students with a critical understanding of these debates and to carve a bigger role for future culinary leaders, equipped with a new set of tools to contribute to change.

This field report will provide context on Ontario college degree programs and culinary education, briefly overview food studies pedagogy, and then expand on the process of development and pedagogical approach of the Bachelor of Food Studies (BFS), as well as the challenges associated with launching a degree of this type.

\section{Ontario college degrees and culinary education transformation}

George Brown College is one of five Institutes of Technology and Advanced Learning (ITALs) in Ontario. The ITAL designation was created in 2003 as a way to bring flexibility, new offerings, and a further emphasis on applied research through partnerships to the college system in Ontario (Ministry of Colleges and Universities, 2003). As an ITAL, George Brown College can provide up to 15 percent of its offerings as degrees, compared to 5 percent for other Colleges of Applied Arts and Technology (Wheelahan et al., 2017, p. 10). The introduction of degrees at 
Ontario colleges began with the passing of the Postsecondary Education Choice and Excellence Act, 2000 (Wheelahan et al., 2017). This act resulted from a number of political changes under the Conservative provincial government at the time which altered the relationships between the government and colleges and universities under a belief that "greater reliance on market forces within higher education" would make the province more competitive in the global arena (Wheelahan et al., 2017, p. 22). The introduction of degrees at colleges was also seen as a response to labour market demands and a recognized need to expand access to bachelor's degrees to students typically underserved by universities (Skolnik et al., 2018).

The act stipulated that colleges may offer degrees only in "applied areas of study" and until 2009, degree titles were required to include applied in the title (Wheelahan et al., 2017, p. 23-24). The inclusion of applied and subsequent ubiquity of the term "applied degrees" suggested to some that these degrees were considerably different than university degrees, as they are in other jurisdictions, such as Alberta (Moodie et al., 2018; Wheelahan et al., 2017). However, degrees at Ontario colleges must comply with the same qualification framework as university degrees. These degrees must also be given approval and undergo external quality assurance by the Postsecondary Education Quality Assessment Board (PEQAB) every five to seven years (Skolnik, 2012, 2016).

The Chef School at George Brown College is the largest in Canada, and one of the largest in North America. It is recognized as one of the top schools for culinary education in Canada, providing a wide variety of certificates and diplomas (George Brown College, 2020). In 2016, the Chef School launched a Bachelor of Commerce in Culinary Management to offer new educational and career pathways to students. In the process of building that degree, it was recognized that there was space in the culinary educational landscape for another degree that focussed on broader food systems issues, leading to the creation of the Bachelor of Food Studies (BFS). This degree creates even more career pathways for students with culinary training, opening the door to careers in food security organizations, policy work, research, and the nonprofit world, in addition to food businesses of all sorts. Increasingly, food professionals are being called upon to assume roles of public leadership, public education, communication, and strategy. For example, Joshna Maharaj, an activist, chef, and author, has documented her work to transform institutional eating in the hospital setting and Johl Whiteduck Ringuette has used his restaurant and catering company, Nish Dish, as a platform to raise awareness about the need for Indigenous food sovereignty (Whiteduck Ringuette, 2020; Maharaj, 2020). The knowledge, skills, and values covered in this degree will become not only "good to know", but also "need to know" to become successful leaders and professionals in the food sector.

This degree is also reflective of calls for culinary education to expand its focus given critiques of limited pathways, the historically colonial nature of culinary study, and lack of diversity in the industry (Deutsch, 2016; Druckman, 2010; Harris \& Giuffre, 2015). Some have even gone so far as to declare culinary education in crisis, noting other issues of dissatisfaction and feelings of under-preparedness from both graduates and industry (Deutsch, 2018; Hertzmann, 2016). Culinary education relies heavily on a master/apprentice model that is more 
pedagogically aligned with vocational training (Deutsch, 2018; Lewis, 2020). This model of training depends on a standardized curriculum that is similar across all major texts in the field and holds both the Chef and European cooking as the ultimate authority (Deutsch, 2018). This rigidity has created specialized, diligent, and respectful cooks, but may stifle alternative thinking and methods at this stage of education, which are left to advanced chefs who have "paid their dues" (Deutsch, 2018, p. 176).

There have been arguments made for more advanced nutrition training as part of standard culinary education, enhanced sustainability knowledge, more creativity, improvisation, and experimentation (Deutsch, 2016; Hertzmann, 2016; Lewis, 2020; Sweeney, 2020). More importantly, there has been increasing discussion regarding issues of race in the culinary world, with customers unwilling to pay more for "ethnic" foods, nutrition narratives and dietetics being blind to diverse cultures and ways of eating, and the labour practices of restaurants called into question (Pandika, 2020; Liu, 2020; Purdy, 2016). Resolution of these discussions must begin in culinary education and requires new thinking. Bashir Munye, a Chef Professor, quoted in a Toronto Star article notes that culinary designations often "judge and present food through a colonial and Eurocentric gaze" (Liu, 2020, para. 7). He has urged for mandatory training on racial literacy, akin to a food handler's certificate or first-aid training (Liu, 2020). Calls for change have led to suggestions for a new "culinary education manifesto" (Deutsch, 2016, p. 2).

A small number of programs globally have begun to do just that, with examples at Technological University Dublin (T.U. Dublin), the Culinary Institute of America, and courses at Johnson \& Wales University (Culinary Institute of America, 2021; Johnson \& Wales University, 2021; Technological University Dublin, 2021). These programs are introducing students to the connections between the food they are cooking and the systems in which it is produced through farm to fork training, sustainability, ethics, and enhanced culinary techniques to "keep pace with the vegan race" and meet specials needs and diets (McConnell, 2020; Shani et al., 2013; Sweeney, 2020; Wang, 2017). Simultaneously, the Ontario Ministry of Colleges and Universities mandated that all culinary college programs must include some form of sustainability in their program learning outcomes as of 2016 (Ministry of Advanced Education and Skills Development, 2016). As a result, new sustainability courses have been incorporated at Ontario colleges offering Culinary Management programs (Godoy, 2019). However, it is recognized, that a single course on sustainability is insufficient to truly create graduates with the complex knowledge of food system challenges and opportunities required for the realities of our world (Godoy, 2019). The new BFS fills this gap with a new pathway for students that brings a broad food studies education together with culinary training to form a uniquely Canadian food studies pedagogy. 


\section{Principles of food studies pedagogy}

Food studies continues to emerge as a distinct field, but draws on a wide variety of disciplines, perspectives, and methods. Recent work has pointed to an emerging "signature pedagogy" for sustainable food systems programs (Valley et al., 2018). The authors draw on Shulman's definition of a signature pedagogy as the "types of teaching that organize the fundamental ways in which future practitioners are educated for their new professions" (Shulman, 2005, p. 52; Valley et al., 2018). Others have supported this vision which finds food studies as a whole to be inherently multi-, inter-, and/or transdisciplinary, practice-facing, and focussed on transformation (Levkoe et al., 2020). This section will outline some key principles of the field of food studies and associated pedagogy.

The multi-, inter-, and transdisciplinary nature of food studies creates a diversity of knowledge and perspectives that is often considered a strength of the field. Incorporating different disciplinary viewpoints, methods, and concepts lends to a rich body of literature central to creating conditions for food studies to contribute to theory and practice. However, as Brady et al. (2015) point out, this feature of food studies also produces a variety of challenges. By incorporating knowledge from different fields, food studies insights may not always align or integrate, depending on the focus in the food system, or the way that a problem is conceptualized. This same lack of congruence may make it challenging for students to decide the most appropriate research methods in their multi- or interdisciplinary work. From a pedagogical perspective, in designing an entire degree, the broad field of food studies combined with culinary industry needs means making decisions about what concepts to engage with, and what to leave out, while ensuring the necessary disciplinary foundations are developed and scaffolded appropriately. There is also the need to provide ways for students to explore their own interests.

Approaching food through a systems lens and understanding complexity is essential to grasp how different structures and processes relate (Ericksen, 2008; Ingram et al., 2020). The complexity of the food system and the ways that food frequently interconnects with numerous other facets of life, politics, economics, the environment, makes it imperative that we study food through a systems lens. Thinking in systems is also commonly highlighted as a program learning outcome across food studies programs and a requirement of "food system analysts" for the future (Ingram et al., 2020, p. 9; Jordan et al., 2014; Valley et al., 2018). A systems lens presents many opportunities to connect to a wide variety of fields and issues but can also present similar challenges to those of multi- and interdisciplinary pedagogy. It is therefore important to ensure that students have the foundations in systems thinking and all aspects of the system, and related concepts to make the necessary connections.

In a session on the current state of food studies in Canada, multiple leading thinkers commented on the nature of food studies scholarship as "practice-facing" and looking to uncover "practical implications for civil society and policy makers" (Brady et al., 2015, p. 4). Indeed, there has been a tradition of activist-scholarship in the field and an argument to "allow ourselves to be drawn out of the ivory tower to participate in those collectives" (Brady et al., 2015, p. 6). 
However, critique comes in many forms. While much activist-scholarship is focussed on alternatives in the margins, this approach can leave many people out of the conversation and out of the food studies fold. The culinary industry in particular has often been left out and is increasingly an area where holistic approaches to understanding food production, distribution, consumption, and waste with an analysis of social, cultural, political, and environmental influences is necessary to success. Culinary professionals need to know how food intersects with health, equity, and sustainability.

In their article outlining a competency approach to sustainable agriculture and food systems education, Galt et al. (2013) note that "competency development is always values-laden" (p. 3). In reality, all learning is values-laden, the product of historical, sociocultural, and political processes and knowledge relations (Halstead et al., 1996). That is particularly apparent in food studies, given that food is so political. After all, "food connects us and divides us" (Brady et al., 2015 , p. 5) and so often food pedagogy is focussed on getting us to change how and what we eat (Flowers \& Swan, 2016; Swan \& Flowers, 2015). Key features of many food studies programs revolve around civic engagement, collective action, and transformation (Valley et al., 2018). However, as Valley et al. (2020) note, questions of equity are often missing from these curriculums, or they are not clearly stated as goals.

The issues of equity in the food system need to be grappled with in any food studies curriculum, as white sensitivities and universalism have often featured, even in alternative food movements and programming (Guthman, 2008b; Slocum, 2007; Swan \& Flowers, 2015). To grapple with equity issues, food studies must be reflexive. It is therefore essential that approaches to the study of food include opportunities for reflexivity. Faculty and students must constantly be reevaluating their approaches, assumptions and become comfortable in the weeds (Alkon \& Guthman, 2017; DuPuis \& Goodman, 2005). This is especially true in an era of globalization, and an increasing recognition that culinary institutions have been embedded in notions of white supremacy. Culinary students must learn to become comfortable with discomfort and understand systems of oppression and ways to oppose them.

\section{Development of the Bachelor of Food Studies}

The vision leading the development of the program is the need to operationalize change within the food industry, from server to CEO. Choices within the food system relate to some of the biggest challenges of our time: How do we address chronic disease, waste, climate change, rapid urbanization, technological change, hunger, and inequity? Despite the weight of these questions, food holds inspiring opportunities through its pleasures, authenticity, flavours, conviviality, and ability to be part of the solutions to some of the world's most complex and pressing problems. The aim of the program is to equip the food leaders of tomorrow with the necessary skills, insights, and knowledge to help address these problems. 
Realizing this vision is challenging but aligns well with food studies pedagogy. The process began with determining what knowledge, skills, insights, attitudes, and attributes would be required to create graduates able to contribute to solutions. The first step of the process was to create program learning outcomes that set out this vision. These program learning outcomes also had to align with the degree-level standards of the Ontario Qualifications Framework, ensuring students acquire the anticipated skills related to research, critical thinking, breadth and depth of knowledge, and communication, to name a few.

The program learning outcomes are as follows:

1. Articulate the interconnected structures and functions of food systems at the local, national, and international levels.

2. Analyze social, cultural, political, and environmental influences on current and emerging food-related theory, policy, and practice.

3. Recommend informed responses to both practical and scholarly issues and challenges using insights from food systems theory and the study of global cuisine.

4. Acquire foundational culinary skill proficiency and operational knowledge appropriate to entry into the culinary industry.

5. Integrate a healthy, equitable, and sustainable food systems perspective into culinary theory and practice.

6. Construct coherent arguments to address debates within the broad field of food studies.

7. Appraise research methodologies used across disciplines related to food studies.

8. Communicate effectively in a variety of formats appropriate to academic, government, nonprofit, business, and media environments.

9. Articulate how uncertainty, ambiguity and limits to knowledge influence perception and interpretation of debates in food studies and consider issues from multiple perspectives.

10. Demonstrate curiosity, initiative, integrity, collaboration, and social responsibility in personal and professional settings related to food.

From here, we began to brainstorm, at a deeper level, the content, skills, experience, and the types of courses that could scaffold the knowledge required to graduate and meet these program outcomes. We put together course titles and course descriptions with as much detail as possible and laid out the order in which we wanted them to unfold. The unique ability to think through a four year food studies curriculum allows for scaffolding that may not be available when teaching an elective food studies course; however, there is also significant work to ensure that we are covering the breadth of knowledge that might normally be covered in other courses of a four year bachelor's degree. Simultaneously, we began to think through when and where to introduce key concepts needed to understand food systems such as systems thinking, globalization, and civil society. Once complete, this package was sent out to our Program Advisory Committee, and additional industry partners, and academics for review. 
A Program Advisory Committee (PAC) is a required part of any program development at a college. The PAC, in the context of colleges, is usually made up of industry professionals and is meant to advise on what students need to know to be successful in industry as well as advancements in the field, such as technology, that might change the required curriculum. Given that we wanted students to be open to a variety of pathways beyond the traditional chef, we felt it imperative to have a diverse PAC made up of professionals from every part of the food chain including farmers, distributors, and consumer-facing organizations. The PAC contains people from food non-profits and anti-poverty organizations, academia, Indigenous food organizations, local food hubs, restaurants, local government, food history and culture organizations, and the traditional foodservice sector. The development team met with the PAC early in the process to get their feedback.

The PAC was critical in ensuring we covered everything necessary to meet our program learning outcomes, but also in pushing us to better deal with aspects of the curriculum they knew best - including a chef who emphasized the development of critical thinking and creativity to be able to adjust to seasonality. A representative from a food non-profit brought language around community food access to our attention - reminding us of the importance of the terminology we use and the precision that is needed in certain cases. We had included food security throughout the curriculum, but the terminology of "community food access" was important to this organization, which highlights the food-access barriers of marginalized communities and neighbourhoods within Toronto - revealing issues of race and equity more clearly. We were also pushed on the inclusion and integration of Indigenous food systems and knowledge, to consider how we were going beyond "sprinkling" this knowledge throughout to true integration. This will be discussed further below.

After meeting with the PAC, we began work to further develop course outlines and potential assignments. Given that we did not yet have approval, these were not full course syllabi, but an idea of the types of readings and assignments that would be used in each course. These course outlines, along with narratives to unpack how the degree met the degree-level standards, as well as details about the college, services, the student experience, and the demand for the program were all put together in an application for the degree.

Once the full application was submitted to the Ministry of Colleges and Universities and sent to the PEQAB board, the next major step in the process was a Panel Review, where two experts in the field of food studies reviewed the program application. Two days of "site visit" meetings were conducted online due to Covid-19 travel restrictions. These meetings gave the panel the opportunity to ask questions of the development team, relevant faculty, college administrators, professional development and faculty support staff, student support staff, the PAC, and students in the other Chef School programs. The final panel report provided some small suggestions for curriculum scaffolding and the supports required for community-engaged learning but was overall very positive.

At the time of writing, we have received final approval from the Ministry of Colleges and Universities and launched our first cohort in Fall 2021. 
Operationalizing food studies pedagogy: What can food studies bring to culinary education?

With final approval, the real work begins to bring the program vision to reality. There are still many challenges ahead, but we are encouraged to explore what food studies brings to culinary education. This section outlines some of the ways that food studies can complement culinary education.

\section{Interdisciplinarity}

Students will be introduced to a breadth of knowledge from a variety of disciplines covering everything from ecology, history, culture, environmental studies, politics, policy, law, transitions, consumption, and nutrition, in addition to many hours of culinary training. A key challenge of program development was simultaneously thinking through how to have students meet the program learning outcomes, while covering everything needed to be engaged citizens navigating the food system. For example, hegemony needs to be introduced before you can explore a term such as "hegemonic nutrition" (Kimura et al., 2014, p. 39). Or, as recently examined in Valley et al. (2020), students must first understand basic terminology of equity such as implicit/explicit bias, white supremacy, structural racism, intersectional oppression, and white privilege before understanding how these concepts can be traced in historical terms, and what sort of processes can promote equity in food systems today. Work also remains to truly integrate these types of lessons of the food studies curriculum throughout the culinary curriculum to ensure that students can learn to apply theory to practice.

\section{Practice-facing and systemic lens}

While food studies are characterized as practice-facing and requiring academics to be "drawn out of the ivory tower", there is still a dearth of research that focuses on how mainstream parts of the food system can contribute to change- however small (Brady et al., 2015, p. 6). It is only recently that there has been interest from food studies in the food-service industry. Research is beginning to emerge on the role that restaurants and chefs can play in creating movement towards sustainability (Higgins-Desbiolles \& Wijesinghe, 2019; Nelson et al., 2017). Literature has shown, however, that sustainable restaurant conceptualizations and research have tended to focus narrowly on ecological sustainability to the detriment of a more holistic sustainability that takes other elements of society and the economy into account (Higgins-Desbiolles et al., 2019). Focusing on more holistic sustainability is imperative in a time when problems are often so interconnected to all facets of society. The curriculum of the degree needs to be oriented towards people in all aspects of the food sector to broaden pathways. This comprehensive view of the food system is a requirement to make valid risk assessments for businesses and organizations in 
all areas of the food sector. Degrees offered at Ontario colleges are required to have a work component. Students will be applying theory to practice in a real work setting. Students will also have two community-engaged learning opportunities of sixteen hours each, where they will be working on smaller projects, drawing on what they are learning in courses on Food, Equity and City, and Food and the Non-Profit Sector. Sending students out into organizations requires preparation in a number of on-the-job skills that will allow them to adapt to any situation.

\section{Values-based, transformative}

A comprehensive and systemic view of the food system is also necessary to make change. This normative and transformative goal is understood to be a key component of food-systems programming - working towards a more equitable and sustainable food system (Anderson et al., 2019; Niewolny et al., 2012; Valley et al., 2018, 2020). This transformation necessitates collective action as demonstrated by numerous food studies scholars and highlighted as a pedagogical requirement. The degree will reckon with the challenges and complexity inherent in trying to balance all facets of sustainability while grappling with the best ways to make immediate and lasting change.

In a recent commentary arguing for critical food literacy on college and university campuses, Classens and Sytsma (2020, p. 8) argue that "institutions should be invested in ensuring that all students - not only food studies students - are exposed to critical food literacy training." The authors tie this need to the high incidence of food insecurity on campuses (Classens \& Sytsma, 2020). The practical application of the knowledge being created in the Bachelor of Food Studies provides a potential opening not only to influence the Chef School, but also to bring new programming and knowledge to all of George Brown College.

\section{Need for reflexivity}

An area of much needed continued work revolves around "decolonization" or "Indigenization" of the curriculum (Wilson, 2018; Appleton, 2019; Tuck \& Yang, 2012). We understand that these terms are fraught with their own underlying assumptions, debates, and uses. We know that we are not the ones to take the lead on this work. However, we are committed to seeing that the required work happens, understanding that this is not an overnight project, that we have not arrived, and this will take concerted effort over a long period of time. Thoroughly integrating and scaffolding Indigenous perspectives, knowledge, and ways of learning throughout the degree requires deep re-thinking and a "pedagogy of discomfort" (Kepkiewicz, 2015, p. 185). Food studies has begun to grapple with these issues, with fraught debates around land, terminology, and the way forward (Coté, 2016; Daigle, 2019; Grey \& Patel, 2015; Kepkiewicz, 2020; Kepkiewicz \& Dale, 2018). However, we are encouraged by new resources and emerging scholars that highlight Indigenous voices and issues in great detail (Settee \& Shukla, 2020). 
A parallel path of work deals with structural racism in the food system (Meek \& Tarlau, 2015; Slocum \& Saldanha, 2016). Again, much work is already under way on this issue, but more and continued work will be required. The issue of food and race is not new, with authors bringing attention to the "whiteness" of community food organizations and movements, and the fact that Black communities are often the object of food pedagogy and research, rather than active participants (Billings \& Cabbil, 2011; Guthman, 2008a, 2008b; Jones, 2019; Slocum, 2007). We are in a unique moment where commitment and research are burgeoning on this issue, with the Canadian Association for Food Studies (CAFS) committing to resources, and lists about structural racism in the U.S. updated every year (CAFS, 2020; Kelly et al., 2020). However, Valley et al. (2020) find that there are gaps in programs employing discourses of anti-oppression, anti-racism, and decolonization, or of intersectionality. We hope this degree can be part of efforts to fill that gap.

Conversations of race and culture are also not new to the restaurant and hospitality industry. However, there has been new attention, given scandals at leading food magazines and recent dialogue around the lack of diversity in the restaurant industry (Ore, 2020; Be Inclusive in Hospitality, 2020; EATT, n.d.). In June 2020, the Editor-in-Chief of Bon Appétit resigned after a photo of him impersonating a Puerto Rican man circulated online, followed by the exit of VP of Video after racist and homophobic tweets resurfaced (Heil, 2020). This event became a catalyst for a flurry of accusations, outing the toxic work culture at the magazine, and its sister publication Eater, including discriminatory behaviour, hiring practices, and pay inequities (Premack, 2020). These events rekindled discussions about problems throughout the hospitality industry, and the food media that covers the latest restaurants and food trends (Erway, 2020; Giorgis, 2020). These discussions are ongoing, with other events in the last few years opening dialogue about food media's racial bias, "food gentrification", and cultural appropriation (Alang, 2020; Ho, 2014; Weissman, 2016). The implosion at Bon Appétit highlighted again just how prevalent the culture of inequality and structural racism is across the food industry and the need for tremendous work - work that can begin, in part, at culinary schools and with examination of culinary curricula (Abad-Santos, 2020).

Students will be expected to operationalize these principles and insights in their culinary practice. The degree students will be leaders in the culinary school and the culinary community, possessing a critical food literacy that can have wide-reaching impacts (Classens \& Sytsma, 2020; Sumner, 2013; Yamashita \& Robinson, 2016). A key tenet of the degree is the way that we hope to differentiate between critical thinking, creative thinking, and integrative thinking, drawing on definitions from the Association of American Colleges and Universities (AAC\&U, 2009a, AAC\&U, 2009b). Integrative thinking and learning requires students to build understanding across the curriculum and co-curriculum, going beyond simple connection-making to synthesizing and transferring knowledge within and beyond campus (AAC\&U, 2009b). While critical thinking is characterized by comprehensive exploration of issues, ideas, artifacts, and events before making conclusions (AAC\&U, 2009a), we would argue that it is often associated with challenging the status quo. Finally, creative thinking is "both the capacity to combine or 
synthesize existing ideas, images, or expertise in original and imaginative ways" (AAC\&U, 2009a, p. 1). Creative thinking is "characterized by innovation, divergent thinking and risk taking" (AAC\&U, 2009a, p. 1). These three linked but different thinking capacities are critical to realizing the interdisciplinary, practice-facing, systems-oriented, transformative, values-based, and reflexive education that food studies demand. Food studies brings new lenses to culinary students and will be a key differentiator in their ability to think critically and improvise in innovative ways (Deutsch, 2018).

\section{What can culinary education bring to food studies?}

There has already been considerable interest in bringing cooking into food studies programming. However, no program in Canada currently offers a full culinary education in conjunction with the food studies curriculum. Scholars have pointed to de-skilling as an important trend in the lack of food literacy among populations (Slater, 2017). Operationalization of food system sustainability may occur, in part through re-skilling, but requires a more holistic knowledge of systemic barriers to access, issues of sustainability, and possibilities for change. Graduates of the Bachelor of Food Studies will bring unique perspectives to their work as those trained in the culinary field in conjunction with a food studies education. In courses such as The Evolving Kitchen, students will take a deep dive into how to transform the way we think about the culinary arts, bringing in fermentation, canning and preservation, and utilization - skills that have been shown to have transformative potential even at a smaller scale (Gabaccia et al., 2019). Having cooking skills and knowledge of how mainstream kitchens think about food will be an important factor in seeing transformative potential throughout the food system. This dual skillset will allow students to contribute to operationalization of food studies insights as part of a practice-facing and transformative pedagogy. Finally, students with knowledge of both alternatives and mainstream practices in culinary arts will be able to better situate solutions within a systemic context.

Culinary education also demands the development of practical skills and competencies. As mentioned, food studies pedagogy is distinctly practice-facing, which makes experiential learning a requirement. Kitchens are inherently team environments where students work together to deliver on a commitment to service, artistry, and innovation. Students must demonstrate the ability to work in teams in conjunction with a capacity to work under pressure and manage their time. The experience of working in a kitchen is unique and demands strict attention to detail, where diners hold new power in the world of instant online reviews (Luca, 2016). Students also learn how to work effectively in a hierarchy, a skill required in a wide variety of professions.

Beyond the practical skills of cooking, time management, teamwork, and attention to detail, culinary education brings the ability to operationalize sustainability, equity, and health in the industry. Thinking about how to design a program that incorporates food studies while meeting the needs of real students with real desires to enter the culinary world is important. What 
is the knowledge required to be successful today and into the future? The fields of culinary education and food studies sometimes have different worldviews, with their own norms and values. These two groups do not always understand each other or respect what each brings to the table. Operationalization is deserving of theory and academic study. Much of the scholar-activist research of food studies focuses on alternatives - sites on the edges of the food system. The goal of the program is to attempt to straddle these divides. We have a unique opportunity to bring together culinary educators and food studies educators to find areas of common ground in creating and operationalizing change. We want to educate scholars to become "actionists"-a cohort who can go out into the world and create change (Ballamingie \& Levkoe, 2021, p. 130). We hope to develop students who do not just want to study the food system, but to implement changes. This has its own inherent challenges. We can present students with a comprehensive education in food studies, teach them about the inequities in the system, the sustainability challenges, and health outcomes, but they must go out into the world and decide what to do with this knowledge.

\section{Challenges: Managing an evolving food and education landscape}

Building a new degree at an Ontario college is not without its challenges. Colleges are still relatively new to offering degrees in Ontario and, as a result, issues are still evolving (Galea, 2015). Major obstacles facing many of these degrees involve questions of legitimacy and academic rigour. Students and faculty at other institutions have expressed concern over how the degrees are perceived as opposed to university degrees (Hurley \& Sá, 2013; Wheelahan et al., 2017). However, many in the industry have not voiced the same apprehension (Wheelahan et al., 2017). While the perception and legitimacy of Ontario college degrees may be slowly shifting, this acceptance may be related to the fields that many college degrees occupy, where students have traditionally been graduating from colleges with vocational diplomas (Wheelahan et al., 2017). This industry perception may be the case for the BFS degree, but given that we anticipate students to have broader career pathways, there will be work to maintain academic rigour and build the reputation of the degree. It is also important to revisit one of the key motivations of offering degrees at Ontario colleges - to serve student populations that are traditionally underserved by universities (Skolnik et al., 2018).

The relative newness of degrees at Ontario colleges means that there is still institutional capacity building that needs to occur. Surveys of students have shown that satisfaction with college services is much lower for degree students than students in diploma and certificate programs (Wheelahan et al., 2017). To keep pace, there will need to be a continued emphasis on developing the writing and research supports for students as we offer more degrees. There have also been concerns at colleges offering degrees around creating "two tiers" of faculty, those with PhDs who teach in the degrees and those who do not have PhDs and teach in diplomas (Wheelahan et al., 2017). Professors who have more traditional vocational training are 
concerned they would not be hired for their own jobs if they applied today (Wheelahan et al., 2017). There is also concern that diplomas may be less valued over time if more degrees are offered in the discipline (Wheelahan et al., 2017).

These concerns are exacerbated by the need for degree faculty and programs to engage in applied research as part of the requirements of PEQAB. This research component involves intervals outside of teaching duties, which changes the traditional role and time allocation of faculty. College faculty labour is governed differently than universities, with a collective bargaining agreement that is the same for all college faculty across Ontario. The Chef School is fortunate to have a number of faculty with $\mathrm{PhDs}$ and Master's degrees. However, sufficient labour power and diversity of experiences will be something to consider in continuing to build strong faculty connections and cohesiveness.

Beyond the challenges of delivering degrees in the college setting, the food studies curriculum is heavily impacted by evolving societal crises. When the Covid-19 pandemic was officially declared in March 2020, initial work on the Bachelor of Food Studies had been completed. However, it is clear to us that this moment will have lasting impacts on our food system, our institutions, our education system, and the way we teach and learn. As faculty, we are having to learn new skills and pedagogies for online teaching, making sure that content is "bite-sized" and accessible to students in new and creative ways. The move to more online teaching also demands new questions, as recently outlined by scholars, on teaching "food from somewhere from nowhere" (Levkoe et al., 2020). How do we continue to offer high quality, experiential, and skills-focussed education online? The culinary school is already finding that the online experience has changed the skills students are acquiring by forcing them to source their own products and apply food theory in novel ways while making choices about what to buy and possible substitutions.

Simultaneously, like colleges and universities across the country, George Brown College is facing potential budget shortfalls as a result of the Covid-19 pandemic, requiring creativity to ensure the success of the program while maintaining a commitment to justice, equity, and sustainability. However, it may also mean time to take stock and strengthen the program, thinking through the implications of online learning and the impacts of the pandemic on food systems to adjust syllabi and curriculum to reflect new realities of the world. This, in turn, can contribute to more effective food studies pedagogy, which will benefit students, the food industry and society as a whole.

\section{Conclusion}

The Covid-19 pandemic has exposed the cracks in the food system. These problems have always been there, but not as visible to all citizens. The turbulence across the entire food sector, and in particular the culinary and hospitality sector, has reinforced the need for a more holistic approach to culinary education and new options for students to examine the food system while mastering a 
variety of culinary techniques and skills. This diverse skillset will become increasingly important to succeed in the world.

We hope that this degree will contribute to the development of this diverse skillset and to the Chef School and culinary industry as a whole in dealing with the changing landscape of the food system. The Bachelor of Food Studies degree will bring a new focus on justice and equity, sustainability and health, and a new awareness of how these broader societal issues can be examined at George Brown College. We hope that this new focus on the culinary industry will also offer opportunities for food studies scholarship to reach food industry workers and build unique skillsets and knowledge that prepare graduates to operationalize meaningful change within the sector. In the Food Studies spirit of reflexivity, we will continue to evaluate this degree beyond traditional metrics of higher education reviews and to consider how the degree is meeting its broader vision to create change in the food system. We will consider whether students are becoming highly educated food professionals with unique insights on the pleasures of food and the underlying knowledge of issues throughout the food system. It is our ambitious goal to develop a food studies pedagogy that will equip the next generation of food professionals with the skills and knowledge they need to lead and thrive in a turbulent world.

\section{Acknowledgments}

We would like to express our sincere thanks to Jennifer Sumner and Michael Classens for their support and comments as we developed this field report. We'd also like to show our appreciation for all the people with whom we had conversations with as we developed this degree.

\section{References}

Abad-Santos, A. (2020, June 11). The food world is imploding over structural racism. The problems are much bigger than Bon Appétit. Vox. https:/www.vox.com/thegoods/21287732/bon-appetit-sohla-adam-rapoport-resigned-duckor-food-racism

Alang, N. (2020, May 20). Alison Roman, Bon Appétit, and the 'global pantry' problem. Eater. https://www.eater.com/2020/5/20/21262304/global-pantry-alison-roman-bon-appetit

Alkon, A., \& Guthman, J. (Eds.). (2017). The new food activism: Opposition, cooperation, and collective action. University of California Press.

Anderson, C. R., Binimelis, R., Pimbert, M. P., \& Rivera-Ferre, M. G. (2019). Introduction to the symposium on critical adult education in food movements: Learning for transformation in and beyond food movements - the why, where, how and the what next? Agriculture and Human Values, 36(3), 521-529. https://doi.org/10.1007/s10460-019-09941-2

Appleton, N. S. (2019, February 4). Do not 'decolonize'...If you are not decolonizing: Progressive language and planning beyond a hollow academic rebranding. Critical Ethnic 
Studies Blog. http://www.criticalethnicstudiesjournal.org/blog/2019/1/21/do-notdecolonize-if-you-are-not-decolonizing-alternate-language-to-navigate-desires-forprogressive-academia-6y $5 \mathrm{sg}$

Association of American Colleges and Universities (AAC\&U). (2009a). Creative thinking VALUE rubric. https://www.aacu.org/value/rubrics/creative-thinking

Association of American Colleges and Universities (AAC\&U). (2009b). Integrative and applied learning VALUE rubric. https://www.aacu.org/value/rubrics/integrative-learning

Ballamingie, P., \& Levkoe, C. (2021). Wayne Roberts: Food systems thinker, public intellectual, “actionist." Canadian Food Studies / La Revue Canadienne Des Études Sur l'alimentation, 8(3), 130-145. https://doi.org/10.15353/cfs-rcea.v8i3.515Be Inclusive Hospitality. (2020). About us. Be inclusive hospitality. https://bihospitality.co.uk/about/

Billings, D., \& Cabbil, L. (2011). Food justice: What's race got to do with it? Race/Ethnicity: Multidisciplinary Global Contexts, 5(1), 103-112. https://doi.org/10.2979/racethmulglocon.5.1.103

Brady, J., Levkoe, C. Z., \& Szanto, D. (2015). Borders, boundaries, and becoming food studies: Looking back, pushing forward. Canadian Food Studies 2(1), 4-8. https://doi.org/10.15353/cfs-rcea.v2i1.56

Canadian Association for Food Studies (CAFS). (2020, June 9). CAFS statement on racialized police violence and systemic racism. Canadian association for food studies. https://foodstudies.info/blm/

Culinary Institute of America (CIA). (2021). Applied Food Studies Degree. Culinary Institute of America. Retrieved November 22, 2021, from https://www.ciachef.edu/cia-applied-foodstudies-bachelors-degree-program/

Classens, M., \& Sytsma, E. (2020). Student food literacy, critical food systems pedagogy, and the responsibility of postsecondary institutions. Canadian Food Studies 7(1), 8-19. https://doi.org/10.15353/cfs-rcea.v7i1.370

Coté, C. (2016). "Indigenizing" food sovereignty. Revitalizing Indigenous food practices and ecological knowledges in Canada and the United States. Humanities, 5(3), 57. https://doi.org/10.3390/h5030057

Daigle, M. (2019). Tracing the terrain of Indigenous food sovereignties. The Journal of Peasant Studies, 46(2), 297-315. https://doi.org/10.1080/03066150.2017.1324423

Deutsch, J. (2016). Revolutionizing culinary education: Can cooking save our food system? Dublin Gastronomy Symposium. https://arrow.tudublin.ie/cgi/viewcontent.cgi?article=1098\&context $=$ dgs

Deutsch, J. (2018). Can improvisation save culinary education? Liminalities: A Journal of Performance Studies, 14(1), 169-184.

Druckman, C. (2010). Why are there no great women chefs? Gastronomica, 10(1), 24-31. https://doi.org/10.1525/gfc.2010.10.1.24 
DuPuis, E. M., \& Goodman, D. (2005). Should we go "home" to eat?: Toward a reflexive politics of localism. Journal of Rural Studies, 21(3), 359-371. https://doi.org/10.1016/j.jrurstud.2005.05.011

Equity at the Table (EATT). (n.d.). About. Equity at the Table (EATT). https://equityatthetable.com/about/

Ericksen, P. J. (2008). Conceptualizing food systems for global environmental change research. Global Environmental Change, 18(1), 234-245. https://doi.org/10.1016/j.gloenvcha.2007.09.002

Erway, C. (2020, June 26). Food media must work harder to fix its racism problem. Grub Street. https://www.grubstreet.com/2020/06/food-media-must-work-harder-to-fix-racism.html

Flowers, R., \& Swan, E. (Eds.). (2016). Food Pedagogies. Routledge.

Gabaccia, D., Frimpong, N., \& MacCulloch, G. (2019). Preservation pedagogy. Gastronomica, 19(3), 6-7. https://doi.org/10.1525/gfc.2019.19.3.6

Galea, J. (2015). Ontario colleges and the introduction of degrees: Mission drift or sustaining the mission? [Unpublished doctoral dissertation, University of Toronto]. TSpace. https://tspace.library.utoronto.ca/handle/1807/70792

Galt, R. E., Parr, D., \& Jagannath, J. (2013). Facilitating competency development in sustainable agriculture and food systems education: A self-assessment approach. International Journal of Agricultural Sustainability, 11(1), 69-88. https://doi.org/10.1080/14735903.2012.683569

George Brown College. (2020, February 4). Chef School. Hospitality and Culinary Arts. https://www.georgebrown.ca/hospitality-culinary-arts/chef-school

Giorgis, H. (2020, June 16). The table stays white. The Atlantic. https://www.theatlantic.com/culture/archive/2020/06/bon-appetit-and-why-table-stays$\underline{\text { white/613093/ }}$

Godoy, L. (2019). Teaching sustainability to culinary students: Graduating sustainabilityminded chefs? [Unpublished master's thesis, University of Toronto]. TSpace. https://tspace.library.utoronto.ca/bitstream/1807/98027/3/Godoy_Luciana_201911_MA_th esis.pdf

Grey, S., \& Patel, R. (2015). Food sovereignty as decolonization: Some contributions from Indigenous movements to food system and development politics. Agriculture and Human Values, 32(3), 431-444. https://doi.org/10.1007/s10460-014-9548-9

Guthman, J. (2008a). Bringing good food to others: Investigating the subjects of alternative food practice. Cultural Geographies, 15(4), 431-447. https://doi.org/10.1177/1474474008094315

Guthman, J. (2008b). "If they only knew": Color blindness and universalism in California alternative food institutions. The Professional Geographer, 60(3), 387-397. https://doi.org/10.1080/00330120802013679 
Halstead, J. M., Taylor, M.J. (eds.) (1996). Values in Education and Education in Values. Falmer Press.

Harris, D. A., \& Giuffre, P. (2015). Taking the heat: Women chefs and gender inequality in the professional kitchen. Rutgers University Press.

Heil, E. (2020, June 11). Amid accusations of discrimination, Bon Appétit staff vows to 'dismantle racism.' Washington Post.

https://www.washingtonpost.com/news/voraciously/wp/2020/06/10/amid-accusations-ofdiscrimination-bon-appetit-staff-vows-to-dismantle-racism/

Hertzmann, P. (2016). Framework for a new culinary arts curriculum. In M. McWilliams (Ed.), Food and communication: Proceedings of the Oxford symposium on food and cookery 2015. Prospect Books.

Higgins-Desbiolles, F., Moskwa, E., \& Wijesinghe, G. (2019). How sustainable is sustainable hospitality research? A review of sustainable restaurant literature from 1991 to 2015. Current Issues in Tourism, 22(13), 1551-1580. https://doi.org/10.1080/13683500.2017.1383368

Higgins-Desbiolles, F., \& Wijesinghe, G. (2019). The critical capacities of restaurants as facilitators for transformations to sustainability. Journal of Sustainable Tourism, 27(7), 1080-1105. https://doi.org/10.1080/09669582.2018.1510410

Hilimire, K., \& McLaughlin, B. C. (2015). Students' suggestions for food systems curricula at a liberal arts college. Agroecology and Sustainable Food Systems, 39(8), 845-860. https://doi.org/10.1080/21683565.2015.1050147

Ho, S. (2014, January 23). \#FoodGentrification and culinary rebranding of traditional foods. bitch media. https://www.bitchmedia.org/post/foodgentrification-and-culinary-rebrandingof-traditional-foods

Hurley, P., \& Sá, C. M. (2013). Higher education policy and legitimacy building: The making of a new academic credential in Ontario. Higher Education Quarterly, 67(2), 157-179. https://doi.org/10.1111/hequ.12010

Ingram, J., Ajates, R., Arnall, A., Blake, L., Borrelli, R., Collier, R., de Frece, A., Häsler, B., Lang, T., Pope, H., Reed, K., Sykes, R., Wells, R., \& White, R. (2020). A future workforce of food-system analysts. Nature Food, 1(1), 9-10. https://doi.org/10.1038/s43016-019$\underline{0003-3}$

Jacobsen, K. L., Niewolny, K. L., Schroeder-Moreno, M. S., Horn, M. V., Harmon, A. H., Fanslow, Y. H. C., Williams, M. A., \& Parr, D. (2012). Sustainable agriculture undergraduate degree programs: A land-grant university mission. Journal of Agriculture, Food Systems, and Community Development, 2(3), 13-26. https://doi.org/10.5304/jafscd.2012.023.004

Jones, N. (2019). "It tastes like heaven": Critical and embodied food pedagogy with Black youth in the Anthropocene. Policy Futures in Education, 17(7), 905-923. https://doi.org/10.1177/1478210318810614 
Jordan, N., Grossman, J., Lawrence, P. G., Harmon, A. H., Dyer, W. E., Maxwell, B. D., Cadieux, K. V., Galt, R., Rojas, A., Byker Shanks, C., Ahmed, S., Bass, T., Kebreab, E., Singh, V., Michaels, T., \& Tzenis, C. (2014). New curricula for undergraduate foodsystems education: A sustainable agriculture education perspective. NACTA Journal, 58(4), 302-310.

Johnson \& Wales University (JWU). (2021). Sustainable Food Systems (B.S.). Johnson \& Wales University. Retrieved November 22, 2021, from https://www.jwu.edu/academics/majorsand-programs/sustainable-food-systems.html

Kelly, R., Pirog, R., Guel, A., Henderson, J., Wilcox, K., Wimberg, T., García Polanco, V., Babayode, D., Watson, K., \& Nelson, E. (2020). An annotated bibliography of structural racism present in the U.S. food system. University of Michigan Center for Regional Food Systems. https://www.canr.msu.edu/resources/structural_racism_in_us_food_system

Kepkiewicz, L. (2015). Pedagogy lost? Possibilities for adult learning and solidarity in food activism. Studies in the Education of Adults, 47(2), 185-198. https://doi.org/10.1080/02660830.2015.11661684

Kepkiewicz, L., \& Dale, B. (2018). Keeping 'our' land: Property, agriculture and tensions between Indigenous and settler visions of food sovereignty in Canada. The Journal of Peasant Studies, 46(5), 983-1002. https://doi.org/10.1080/03066150.2018.1439929

Kepkiewicz, L. (2020). Whose land? Complicating settler understandings of land in Canada. An International Journal for Critical Geographies, 19(1), 245-269.

Kimura, A. H., Biltekoff, C., Mudry, J., \& Hayes-Conroy, J. (2014). Nutrition as a project. Gastronomica, 14(3), 34-45. https://doi.org/10.1525/gfc.2014.14.3.34

Levkoe, C. Z., Knezevic, I., Appavoo, D., Moraes, A., \& Scott, S. (2020). Serving up food studies online: Teaching about "food from somewhere" from nowhere. Food, Culture \& Society, 23(3), 434-453. https://doi.org/10.1080/15528014.2020.1754041

Lewis, B. J. (2020). Culinary Sustainability Education: A Culinary Education as Sustainability [Unpublished doctoral dissertation, University of Wisconsin-Stevens Point]. https://minds.wisconsin.edu/bitstream/handle/1793/80513/Lewis\%20\%282020\%2909212 $\underline{0 . p d f}$ ? sequence $=6 \&$ isAllowed $=\mathrm{y}$

Liu, K. (2020, June 21). Restaurant industry looks to reset the table. Toronto Star. https://www.pressreader.com/canada/toronto-star/20200621/281492163573303

Luca, M. (2016). Reviews, reputation, and revenue: The case of Yelp.Com (Working paper No. 12-016). Harvard Business School NOM Unit. https://doi.org/10.2139/ssrn.1928601

Maharaj, J. (2020). Take back the tray: Revolutionizing food in hospitals, schools, and other institutions. ECW Press.

McConnell, O. (2020). Keeping pace with the vegan race: A challenge for culinary arts education. Dublin Gastronomy Symposium.

https://arrow.tudublin.ie/cgi/viewcontent.cgi?article $=1172 \&$ context $=$ dgs 
Meek, D., \& Tarlau, R. (2015). Critical food systems education and the question of race. Journal of Agriculture, Food Systems, and Community Development, 5(4), 131-135. https://doi.org/10.5304/jafscd.2015.054.021

Ministry of Advanced Education and Skills Development. (2016). Culinary management program standard. Government of Ontario.

http://www.tcu.gov.on.ca/pepg/audiences/colleges/progstan/hosptour/culinary_managemen t_53107_e_20160831.pdf

Ministry of Colleges and Universities. (2003, February 10). Eves government expands choice for students, announces new designation for colleges. Newsroom.

https://news.ontario.ca/archive/en/2003/02/10/Eves-government-expands-choice-forstudents-announces-new-designation-for-colleg.html

Moodie, G., Skolnik, M. L., Wheelahan, L., Liu, Q., Simpson, D., \& Adam, E. G. (2018). How are 'applied degrees' applied in Ontario colleges of applied arts and technology? In J. Gallacher \& F. Reeve (Eds.), New frontiers for college education: International perspectives (pp. 137-147). Routledge.

Nelson, P., Beckie, M. A., \& Krogman, N. T. (2017). The "Locavore" chef in Alberta: A situated social practice analysis. Food, Culture \& Society, 20(3), 503-524. https://doi.org/10.1080/15528014.2017.1288798

Niewolny, K. L., Grossman, J. M., Byker, C. J., Helms, J. L., Clark, S. F., Cotton, J. A., \& Jacobsen, K. L. (2012). Sustainable agriculture education and civic engagement: The significance of community-university partnerships in the new agricultural paradigm. Journal of Agriculture, Food Systems, and Community Development, 2(3), 27-42. https://doi.org/10.5304/jafscd.2012.023.005

Ore, J. (2020, June 13). Bon Appétit brownface photo, toxic culture accusations reflect broader racism in food media, says Black foodie. Day 6 CBC radio. https://www.cbc.ca/radio/day6/cops-gets-cancelled-race-based-data-in-policing-reckoningat-bon-appetit-j-k-rowling-bruce-lee-and-more-1.5607756/bon-app $\% \mathrm{C} 3 \%$ A 9 tit-brownfacephoto-toxic-culture-accusations-reflect-broader-racism-in-food-media-says-black-foodie$\underline{1.5607780}$

Pandika, M. (2020, August 3). How to overcome the oppressive whiteness of 'clean eating'. MIC. https://www.mic.com/p/overcoming-the-oppressive-whiteness-of-clean-eating$\underline{18735775}$

Premack, R. (2020, June 9). Bon Appétit's editor in chief just resigned-But staffers of color say there's a "toxic" culture of microaggressions and exclusion that runs far deeper than one man. Business Insider. https://www.businessinsider.com/bon-appetit-adam-rapoport-toxicracism-culture-2020-6

Purdy, C. (2016, April 8). What Americans are willing to pay for "ethnic" restaurant food reveals some deep prejudices. Quartz. https://qz.com/657013/what-americans-are-willingto-pay-for-ethnic-restaurant-food-reveals-some-pretty-deep-prejudices/

Settee, P., \& Shukla, S. (2020). Indigenous food systems: Concepts, cases, and conversations. Canadian Scholars Press. 
Shani, A., Belhassen, Y., \& Soskolne, D. (2013). Teaching professional ethics in culinary studies. International Journal of Contemporary Hospitality Management, 25(3), 447-464. https://doi.org/10.1108/09596111311311062

Shulman, L.S. (2005). Signature pedagogies in the professions. Daedalus, 134, 52-59

Skolnik, M. L. (2012). College baccalaureate degrees and the diversification of baccalaureate production in Ontario. Pages 1-27.

https://tspace.library.utoronto.ca/bitstream/1807/32379/1/M\%20Skolnik\%20$\% 20$ Baccalaureate.pdf

Skolnik, M. L. (2016). How do quality assurance systems accommodate the differences between academic and applied higher education? Higher Education, 71(3), 361-378. https://doi.org/10.1007/s10734-015-9908-4

Skolnik, M. L., Wheelahan, L., Moodie, G., Liu, Q., Adam, E., \& Simpson, D. (2018). Exploring the potential contribution of college bachelor degree programs in Ontario to reducing social inequality. Policy Reviews in Higher Education, 2(2), 176-197. https://doi.org/10.1080/23322969.2018.1455532

Slater, J. (2017). Food literacy: A critical tool in a complex foodscape. Journal of Family \& Consumer Sciences, 109(2), 14-20. https://doi.org/info:doi/10.14307/JFCS109.2.14

Slocum, R. (2007). Whiteness, space and alternative food practice. Geoforum, 38(3), 520-533. https://doi.org/10.1016/j.geoforum.2006.10.006

Slocum, R., \& Saldanha, A. (Eds.). (2016). Geographies of race and food: Fields, bodies, markets. Routledge.

Sumner, J. (2013). Food literacy and adult education: Learning to read the world by eating. Canadian Journal for the Study of Adult Education, 25(2), 79-92.

Swan, E., \& Flowers, R. (2015). Clearing up the table: Food pedagogies and environmental education - contributions, challenges and future agendas. Australian Journal of Environmental Education, 31(1), 146-164. https://doi.org/10.1017/aee.2015.27

Sweeney, A. (2020). Empowering chefs to disrupt the 'disruptors': A diametrical dilemma for mindful learning. Dublin Gastronomy Symposium. https://arrow.tudublin.ie/cgi/viewcontent.cgi?article $=1174 \&$ context $=\mathrm{dgs}$

The Metcalf Foundation. (2008). Food connects us all: Sustainable local food in southern Ontario. The Metcalf Foundation. https://metcalffoundation.com/publication/foodconnects-us-all-sustainable-local-food-in-southern ontario/\#: : text=Food $\% 20$ Connects $\% 20 U s \% 20$ All $\% 20$ aims,points $\% 20$ for $\% 20$ food $\% 20$ sys tem $\% 20$ change.

Tuck, E., \& Yang, K. W. (2012). Decolonization is not a metaphor. Decolonization: Indigeneity, Education \& Society, 1(1), 1-40.

Technological University Dublin. (2021). Botanical Cuisine. Retrieved November 22, 2021, from https://tudublin.ie/study/undergraduate/courses/botanical-cuisine-tu941/ 
Valley, W., Wittman, H., Jordan, N., Ahmed, S., \& Galt, R. (2018). An emerging signature pedagogy for sustainable food systems education. Renewable Agriculture and Food Systems, 33(5), 467-480. https://doi.org/10.1017/S1742170517000199

Valley, W., Anderson, M., Blackstone, N. T., Sterling, E., Betley, E., Akabas, S., Koch, P., Dring, C., Burke, J., \& Spiller, K. (2020). Towards an equity competency model for sustainable food systems education programs. Elementa Science of the Anthropocene, $8(1)$, 33. https://doi.org/10.1525/elementa.428

Wang, Y. (2017). Promoting sustainable consumption behaviors: The impacts of environmental attitudes and governance in a cross-national context. Environment and Behavior, 49(10), 1128-1155. https://doi.org/10.1177/0013916516680264

Weissman, M. (2016, February 16). His Paula Deen takedown went viral. But this food scholar isn't done yet. Washington Post. https:/www.washingtonpost.com/lifestyle/food/his-pauladeen-takedown-went-viral-but-this-food-scholar-has-more-on-hismind/2016/02/12/f83900f8-d031-11e5-88cd-753e80cd29ad_story.html

Wheelahan, L., Skolnik, M. L., Liu, Q., Adam, E. G., \& Simpson, D. (2017). CAAT baccalaureates: What has been their impact on students and colleges? Centre for the study of Canadian and International Higher Education (CIHE) report 2017.04. University of Toronto. https://www.oise.utoronto.ca/pew/wpcontent/uploads/sites/25/2018/02/CAAT_baccalaureates-Report-v4.pdf

Whiteduck Ringuette, J. (2020). Chef Johl Whiteduck Ringuette on Indigenous food sovereignty. Foodism Toronto. https://foodism.to/long-reads/interviews/johl-whiteduck-ringuetteindigenous-food-sovereignty/

Wilson, K. (2018). Pulling together: A guide for Indigenization of post-secondary institutions. BCcampus. https://opentextbc.ca/indigenizationfoundations/.

Yamashita, L., \& Robinson, D. (2016). Making visible the people who feed us: Educating for critical food literacy through multicultural texts. Journal of Agriculture, Food Systems, and Community Development, 6(2), 269-281. https://doi.org/10.5304/jafscd.2016.062.011 